\title{
A Retrospective Study: Risk Factor Analysis of Secondary Bacterial Infection in Pediatric Atopic Dermatitis Patients
}

\author{
Desiana Widityaning Sari ${ }^{1}$, Sawitri ${ }^{1}$, M. Yulianto Listiawan ${ }^{1}$, Dwi Murtiastutik ${ }^{1}$, Linda \\ Astari $^{1}$, Alpha Fardah Athiyyah ${ }^{2}$, Afif Nurul Hidayati ${ }^{1}$ \\ ${ }^{I}$ Department of Dermatology and Venereology, Universitas Airlangga/Dr. Soetomo General Academic \\ Hospital, Universitas Airlangga, Surabaya \\ ${ }^{2}$ Department of Pediatrics, Faculty of Medicine, Universitas Airlangga, Surabaya
}

\begin{abstract}
Background: Atopic Dermatitis (AD) is a complex multifactorial disease that includes defects in skin architecture, immune dysregulation, and changes of skin flora, and it predominantly occurs in infancy and childhood. The defects in skin barrier structures are mentioned as one of the factors that facilitates bacterial colonization. Bacterial infection in AD can worsen the inflammation. It requires treatment with antibiotics, which takes longer therapy time, higher costs, and ultimately affects the patient's quality of life and his/her family members. Purpose: To find out the epidemiology, diagnosis, management of AD, and analyze the risk factors of secondary bacterial infection in new AD patients at the Pediatric Dermatology Division, Dermatovenereology Outpatient Clinic, Dr. Soetomo General Academic Hospital. Methods: This was a retrospective study with a total sampling method. The research data were medical records of new AD patients at the Pediatric Dermatology Division, Dermatovenereology Outpatient Clinic, Dr. Soetomo General Academic Hospital Surabaya from January 2012 to December 2018. Result: There were 404 new patients with AD at the Pediatric Dermatology Division from January 2012 to December 2018, and 210 of them were accompanied by secondary bacterial infection. There was a correlation between a history of dry skin $(\mathrm{p}=0.000)$ with the incidence of secondary bacterial infection in AD patients. Conclusion: In this study, $\mathrm{AD}$ patients with a history of dry skin had a risk of complication such as bacterial secondary infection.
\end{abstract}

Keywords: atopic dermatitis, risk factor, infectious disease.

Correspondence address: Afif Nurul Hidayati, Department of Dermatology and Venereology Faculty of Medicine, Universitas Airlangga / Dr. Soetomo General Academic Hospital / Universitas Airlangga, Surabaya, Jl. Mayjen Prof. Dr. Moestopo No. 6-8 Surabaya 60131, Indonesia. Phone: (031) 5501609, e-mail: afif_nurulhidayati@fk.unair.ac.id.

\section{BACKGROUND}

Atopic Dermatitis (AD) is a complex multifactorial disease that includes defects in skin barrier structures, immune dysregulation, and changes in skin flora which mostly occur in infancy and childhood. Based on the clinical picture, AD can be divided into 3 forms, namely AD in infants (2 months2 years), children (2-12 years), and adolescents (over 12 years). In $\mathrm{AD}$, defects in the skin barrier structure, decreased functional integrity, and reduced regenerability affect immune responses and specific inflammatory reactions. ${ }^{1}$

A phase III study by ISAAC (International Study of Asthma and Allergies in Childhood) involving 1.2 million school children from 98 countries reported that the prevalence of AD in children aged 6-7 years was $7.9 \%$ and $7.3 \%$ in children over 12 years old. This shows an increase in the prevalence of $\mathrm{AD}$, especially in Asia in the last few decades, which is influenced by several factors such as urbanization, changes in lifestyle and dietary habits, as well as an increase in the standard of living and education. Skin barrier defect is mentioned as one of the factors that facilitates bacterial colonization. Infection in AD skin lesions can worsen the inflammation, and it requires treatment with topical or systemic antibiotics. This would require longer therapy times, higher costs, the risk of antibiotic resistance, and ultimately affecting the quality of life for patients and their families. ${ }^{2,3,4}$

In 2014, a cross-sectional study in China reported that $52.3 \%$ of $\mathrm{AD}$ patients of all ages also had secondary infections. AD patients over 11 years old have a higher incidence of infection caused by Staphylococcus aureus compared to children under age groups. In this study, the ratio of AD patients with secondary bacterial infection is half of the total number of AD patients. Therefore, a secondary bacterial infection in $\mathrm{AD}$ is a problem that needs to be addressed because this complication can lead to recurrence in AD. If left untreated, it can lead to several systemic 
infections such as osteomyelitis, septicemia, and endocarditis. ${ }^{5,6,7}$

The risk factors for secondary bacterial infection in $\mathrm{AD}$ have not been determined. Research in China reported the risk factors associated with the incidence of secondary bacterial infection in AD patients: history of allergies, history of AD in infancy, and involvement of the flexor area. This study analyzes the risk factors associated with the incidence of secondary infection in AD patients, which are individual history of atopy, familial history of atopy, dry skin, and involvement of the flexor area. ${ }^{8}$

\section{METHODS}

This was an analytic retrospective study aimed to find out the epidemiology, diagnosis, treatment, and analyze the risk factors of secondary bacterial infection in $\mathrm{AD}$ patients. The data were obtained from the electronic medical records of $\mathrm{AD}$ patients. The data contained identity, history taking, examination, diagnosis, and treatment with a cross-sectional approach. The sample was patients admitted at the Pediatric Dermatology Division, Dermatovenereology
Outpatient Clinic Dr. Soetomo General Academic Hospital from January 2012 to December 2018. The ethical clearance has been obtained from the Ethical Committee of Dr. Soetomo General Academic Hospital Surabaya Number 1758/KEPK/I/2020.

\section{RESULT}

There were 404 new AD patients at the Pediatric Dermatology Division, Dermatovenereology Outpatient Clinic Dr. Soetomo General Academic Hospital from 2012 to 2018 , contributing $13.2 \%$ of the patients of the Pediatric Dermatology Division and $1.8 \%$ of the total patients admitted in the Dermatovenereology Outpatient Clinic Dr. Soetomo General Academic Hospital. Of the 404 new AD patients, 210 of them were presented with secondary bacterial infection, contributing $6.9 \%$ of the patients of the Pediatric Dermatology Division and $0.9 \%$ of the total patients admitted to the Dermatovenereology Outpatient Clinic. Thus, the ratio of AD patients and those with secondary bacterial infection was $1: 0.5$, and the ratio of $\mathrm{AD}$ patients and those presented with other diseases was 1: 0.2 .

Table 1. The distribution of new atopic dermatitis patients and new atopic dermatitis patients with secondary bacterial infection at the Pediatric Dermatology Division, Dermatovenereology Outpatient Clinic, Dr. Soetomo General Academic Hospital

\begin{tabular}{|c|c|c|c|c|c|c|c|c|}
\hline \multirow[b]{2}{*}{ New Patients } & \multicolumn{7}{|c|}{ Year } & \multirow[b]{2}{*}{$\begin{array}{l}\text { Number } \\
(\%)\end{array}$} \\
\hline & $\begin{array}{l}2012 \\
(\%)\end{array}$ & $\begin{array}{c}2013 \\
(\%)\end{array}$ & $\begin{array}{c}2014 \\
(\%)\end{array}$ & $\begin{array}{c}2015 \\
(\%)\end{array}$ & $\begin{array}{c}2016 \\
(\%)\end{array}$ & $\begin{array}{c}2017 \\
(\%)\end{array}$ & $\begin{array}{c}2018 \\
(\%)\end{array}$ & \\
\hline Atopic Dermatitis & $\begin{array}{c}84 \\
(20.7)\end{array}$ & $\begin{array}{c}63 \\
(15.5)\end{array}$ & $\begin{array}{c}46 \\
(11.3)\end{array}$ & $\begin{array}{c}60 \\
(14.8)\end{array}$ & $\begin{array}{c}51 \\
(12.6)\end{array}$ & $\begin{array}{c}53 \\
(14.1)\end{array}$ & $\begin{array}{c}47 \\
(11.6)\end{array}$ & $404(1.8)$ \\
\hline $\begin{array}{l}\text { Atopic Dermatitis \& } \\
\text { Secondary Bacterial } \\
\text { Infection }\end{array}$ & $\begin{array}{c}35 \\
(16.6)\end{array}$ & $\begin{array}{c}24 \\
(11.4)\end{array}$ & $\begin{array}{c}27 \\
(12.8)\end{array}$ & $\begin{array}{c}28 \\
(13.3)\end{array}$ & $\begin{array}{c}23 \\
(10.9)\end{array}$ & $\begin{array}{c}35 \\
(16.6)\end{array}$ & $\begin{array}{c}38 \\
(18.0)\end{array}$ & $210(0.9)$ \\
\hline $\begin{array}{l}\text { Atopic Dermatitis \& } \\
\text { other diseases }\end{array}$ & $\begin{array}{c}17 \\
(18.8)\end{array}$ & $\begin{array}{c}10 \\
(11.1)\end{array}$ & $\begin{array}{c}12 \\
(13.3)\end{array}$ & $\begin{array}{c}10 \\
(11.1)\end{array}$ & $\begin{array}{c}10 \\
(11.1)\end{array}$ & $\begin{array}{c}12 \\
(13.3)\end{array}$ & $\begin{array}{c}19 \\
(21.1)\end{array}$ & $90(0.4)$ \\
\hline $\begin{array}{l}\text { Pediatric } \\
\text { Dermatology } \\
\text { Division }\end{array}$ & $\begin{array}{c}597 \\
(19.6)\end{array}$ & $\begin{array}{c}536 \\
(17.6)\end{array}$ & $\begin{array}{c}489 \\
(16.0)\end{array}$ & $\begin{array}{c}383 \\
(12.5)\end{array}$ & $\begin{array}{c}332 \\
(10.9)\end{array}$ & $\begin{array}{c}340 \\
(11.1)\end{array}$ & $\begin{array}{c}365 \\
(11.9)\end{array}$ & $\begin{array}{l}3,042 \\
(14.2)\end{array}$ \\
\hline $\begin{array}{l}\text { Dermato } \\
\text { Venereology } \\
\text { Outpatient Clinic }\end{array}$ & $\begin{array}{l}4211 \\
(19.7)\end{array}$ & $\begin{array}{c}3840 \\
(17.9)\end{array}$ & $\begin{array}{c}3358 \\
(15.7)\end{array}$ & $\begin{array}{c}2673 \\
(12.5)\end{array}$ & $\begin{array}{c}2545 \\
(11.9)\end{array}$ & $\begin{array}{c}2556 \\
(12)\end{array}$ & $\begin{array}{c}2179 \\
(10.2)\end{array}$ & $\begin{array}{r}21,362 \\
(100)\end{array}$ \\
\hline
\end{tabular}

There were 216 female patients $(53.5 \%)$ and 188 male patients $(46.5 \%)$ admitted at the Pediatric Dermatology Division, Dermatovenereology Outpatient Clinic, Dr. Soetomo General Academic Hospital during 2012-2018. Most AD patients with secondary bacterial infection were males, 112 patients $(53.3 \%)$ than women, 98 patients $(46.7 \%)$. Itching and painful vesicles were the chief complaints in $\mathrm{AD}$ patients with secondary bacterial infection, as observed in 89 patients $(42.4 \%)$. Also, 133 patients $(63.3 \%)$ 
reported that most complaints appeared in less than 1 month.

Most AD patients with secondary bacterial infection, as many as 90 patients $(42.9 \%)$, reported no history of atopy. However, most patients, 69 (32.9\%), had individual history of atopy. This means that the patient has a history of atopy, but none of his/her family has. The atopy type in AD patients with secondary bacterial infection was dominated by allergic rhinitis in 53 patients $(65.4 \%)$. Meanwhile, familial history of atopy in $\mathrm{AD}$ patients was dominated by bronchial asthma and atopic dermatitis, as many as 34 patients each $(66.6 \%)$.

In $\mathrm{AD}$ patients with secondary bacterial infection, most lesions appeared on the hands; 196 patients (93.3\%), followed by legs; 175 patients $(83.3 \%)$, and feet; 149 patients $(70.9 \%)$. Also, in AD patients with secondary bacterial infection, the lesions were dominated by erythema, as many as 176 patients $(83.8 \%)$, followed by crusting as many as 164 patients (78.1\%), and xerosis, as many as 163 patients (77.6\%).
Most AD patients with bacterial secondary, 134 patients $(63.8 \%)$, received treatments with oral antibiotics, $\mathrm{NaCl}$ compresses, moisturizers, and antihistamines. Erythromycin was the most opted antibiotic therapy, as observed in 102 patients (58.6\%), followed by amoxycillin, as observed in 46 patients $(26.4 \%)$, and cloxacillin, as observed in 26 patients $(14.9 \%)$.

This study also analyzed the relationship between individual history of atopy, familial history of atopy, dry skin, and involvement of flexor area as the risk factors of secondary bacterial infection in $\mathrm{AD}$ patients. In this study, dry skin had a p-value $<0.05$ (Table 2). Therefore, there was a positive correlation between dry skin and the incidence of secondary bacterial infection. The univariate analysis was then continued with the multivariate analysis. The confidence interval for dry skin was 3.803-8.774 (Table 3), reaffirming that dry skin is a risk factor for secondary bacterial infection in AD patients.

Table 2. Univariate analysis of variables as the risk factors in atopic dermatitis patients with secondary bacterial infection at the Pediatric Dermatology Division, Dermatovenereology Outpatient Clinic, Dr. Soetomo General Academic Hospital

\begin{tabular}{|c|c|c|c|c|}
\hline \multirow{2}{*}{ Variables } & \multicolumn{2}{|c|}{ Secondary Bacterial Infection } & \multirow{2}{*}{$X^{2}$} & \multirow[b]{2}{*}{$\mathrm{p}$} \\
\hline & Yes & No & & \\
\hline History of atopy in patients or their families & & & 0.275 & 0.600 \\
\hline Yes & 122 & 245 & & \\
\hline No & 88 & 159 & & \\
\hline Dry Skin & & & 95.87 & 0.000 \\
\hline Yes & 162 & 142 & & \\
\hline No & 48 & 262 & & \\
\hline Involvement of the flexor area & & & 3 & 0.083 \\
\hline Yes & 181 & 324 & & \\
\hline No & 29 & 80 & & \\
\hline
\end{tabular}

Table 3. Multivariate analysis of variables as the risk factors in atopic dermatitis patients with secondary bacterial infection at the Pediatric Dermatology Division, Dermatovenereology Outpatient Clinic, Dr. Soetomo General Academic Hospital

$\mathrm{OR}=$ Odds Ratio $; \mathrm{CI}=$ Confidence Interval. 


\section{DISCUSSION}

The risk factors for secondary bacterial infection in $\mathrm{AD}$ are not fully determined. In 2014, a crosssectional study in China reported that $52.3 \%$ of AD patients of all ages had secondary bacterial infection. ${ }^{6}$ This study analyzed the relationship between risk factors and the incidence of secondary bacterial infections in AD. The risk factors examined were individual/familial history of atopy, dry skin, and involvement of the flexor area.

The skin is continuously in contact with the surrounding environment, exposing it to several organisms. ${ }^{8}$ In addition, the surface of the skin contains many products of skin keratinization, such as fat, nitrogen-containing ingredients, and minerals. This is a good environment for the growth of microorganisms. S. epidermidis is a dominant non-pathogenic organism on the skin, and S. aureus is a pathogenic organism that often causes infection. S. aureus is more susceptible to attack skin with chronic epithelial integrity disorders, such as AD. S. aureus causes disease both by producing toxins and inducing pyogenic inflammation. The exotoxin produced by $S$. aureus can cause secondary infection or exacerbation of AD. Superantigens produced by $S$. aureus can penetrate the epidermis and dermis, where they interact with immune cells such as $\mathrm{T}$ and APC cells to cause inflammation. ${ }^{9}$

We found that secondary bacterial infection is more common in $\mathrm{AD}$ patients with a familial history of atopy (122 patients) than those without a familial history of atopy ( 88 patients). However, the univariate analysis showed a p-value of $>0.05$. It means no correlation between individual and familial history of atopy. In several studies, individual and familial history of atopy has been associated with the incidence of AD itself. In 2017, research in Padang stated that most AD patients have a familial history of atopy. ${ }^{10}$ Research at the Dr. Mohammad Hoesin Palembang from 2011 to 2013 stated that familial history of AD includes $\mathrm{AD}(25.8 \%)$, allergic rhinitis $(6.5 \%)$, asthma (12.9\%), and allergic conjunctivitis (3.2\%). ${ }^{11}$ However, no research has discussed the correlation between a history of atopy and the incidence of secondary infection in $\mathrm{AD}$ patients.

This study also analyzed dry skin as a risk factor for secondary bacterial infection in $\mathrm{AD}$ patients. It is showed that 162 patients experienced dry skin, and the univariate analysis resulted in a p-value $<0.05$. It means that there was a correlation between dry skin and secondary bacterial infection in $\mathrm{AD}$ patients. Furthermore, a multicenter study in China in 2016 presented that dry skin is one of the risk factors for secondary bacterial infection in AD. ${ }^{12}$ Dry skin in AD is associated with the mutation of filaggrin (FLG).
There are two roles of FLG in the skin: a barrier and a growth modulator for $S$. aureus. FLG is converted into hygroscopic amino acids in the skin, including urocanic acid (UCA) and pyrrolidone carboxylic acid (PCA). UCA and PCA are components of natural moisturizing factors (NMF) that hydrate and maintain the $\mathrm{pH}$ of the stratum corneum acid. ${ }^{7}$ Reduced NMF results in abnormalities in the stratum corneum such as dry skin, scaly skin, wrinkled skin, and fissures.

This study found that most lesions involved the flexor area, as observed in 181 patients. However, the univariate analysis resulted in a p-value $>0.05$, which means there is no correlation between the involvement of the flexor area and the incidence of secondary bacterial infection. There is still no study that further discusses the incidence of secondary bacterial infection and the location of the lesions. The generally known theory is the predilection location of $\mathrm{AD}$ according to the patient's age. At $0-2$ years of age, the predilection location is on the face (forehead, cheeks). At 2-12 years of age, the location of predilection is in the flexors and folds such as the folds of the elbows, knees, neck, and wrists. At over 12 years of age, the distribution of the lesions is less characteristic but more frequent on the trunk and extensors.

The management of $\mathrm{AD}$ consists of improving the skin barrier, reducing inflammation, reducing itching, avoiding the triggering factors of $\mathrm{AD}$, providing information, education, and psychological counseling or intervention and consultation. Education for parents and caregivers is an important part of managing $\mathrm{AD}$, especially what is expected to control the flare rather than to cure. Furthermore, the main goal for atopic dermatitis is to control the symptom, reduce the risk of complications, and prevent relapse..$^{13,14,15,16}$ In this study, 189 patients $(89.5 \%)$ received emollient therapy in the form of urea $(69.5 \%)$, and the rest was in the form of bio cream. Emollients effectively repair the skin barrier as they reduce transepidermal water loss (TEWL) and increase the skin's ability to retain water. A total of 23 patients $(11 \%)$ received oral steroid therapy, and 42 patients $(20 \%)$ received topical steroid therapy. AD patients with secondary bacterial infection also received additional therapies, such as oral antibiotics, as observed in 186 patients (88.6\%), and erythromycin was the most opted antibiotic, as observed in 149 patients (71\%). This was in accordance with the Clinical Practice Guideline of Dr. Soetomo General Academic Hospital. Additional therapies include $\mathrm{NaCl}$ dressings, as observed in 169 patients $(80.5 \%)$, and topical antibiotic therapy, as observed in 60 patients $(28.7 \%)$.

From 2012 to 2018,210 AD patients with secondary bacterial infection were admitted to the 
Pediatric Dermatology Division, Dermatovenereology Outpatient Clinic, Dr. Soetomo General Academic Hospital. This contributed to $51.9 \%$ of all AD patients, $6.9 \%$ of total patients admitted to the Pediatric Dermatology Division, and $0.9 \%$ of the total patients admitted in the Dermatovenereology Outpatient Clinic. To conclude, dry skin was the risk factor for secondary bacterial infection in AD patients (OR 5.776, 95\% CI $3.803-8.774, \mathrm{P}<.05)$. Accurate and proper medical records of $\mathrm{AD}$ cases are important for better history taking, diagnosis establishment, monitoring, and follow-up treatment. The records should cover the identity of the patient, risk factors, and SCORAD.

\section{REFERENCESS}

1. Kennedy K, Heimall J, Spergel JM. Advances in atopic dermatitis in 2017. J Allergy Clin Immunol 2017;142(6):1740-7.

2. Lubis M. Association between bacterial infection and severity of atopic dermatitis. Indian $\mathrm{J}$ Med Res 2018;7(5):18-20.

3. Fishbein AB, Mueller K, Kruse L. Sleep disturbance in children with moderate/severe atopic dermatitis: A case-control study. J Am Acad Dermatol 2018;78(2):336-41.

4. Nowicka D, Grywalska I. The role of immune defects and colonization of Staphylococcus aureus in the pathogenesis of atopic dermatitis. Anal Cell Pathol 2018, Article ID 1956403.

5. Pyun BY. Natural history and risk factor of atopic dermatitis in children. Allergy Asthma Immunol Res 2015;7(2):101-5.

6. Wang X, Shi XD, Li LF, Zhou P, Shen YW. Classification and possible bacterial infection in outpatient with eczema and dermatitis in China. Medicine 2017;96:35(e7955).

7. Ong PY, Leung DYM. Bacterial and viral infections in atopic dermatitis: a comprehensive review. Clin Rev allergy Immunol 2016;51(3):329-37.

8. Lyons JJ, Milner JD, Stone KD. Atopic dermatitis in children: clinical features, pathophysiology, and treatment. Immunol Allergy Clin North Am 2015;35(1):161-8.

9. Breuer K, Haussler S, Kapp A, Werfel T. Staphylococcus aureus: colonizing features and influence of an antibacterial treatment in adults with atopic dermatitis. $\mathrm{Br} \mathrm{J}$ Dermatol 2002;147(1):55-61.

10. Lubbe, J. Secondary infections in patients with atopic dermatitis. Am J Clin Dermatol 2013;4(9):641-54.

11. Eliska N, Thaha MA, Anwar C. Faktor risiko pada dermatitis atopik. J Ked Kes 2015; 2(1): 143-9.

12. Mei X, Li L. Risk factor for secondary infection in foot eczema: a multicenter study. Int J Clin Exp Med 2016;9(6):11974-81.

13. Rubel, D. Thirumoorthy T, Soebaryo RW, Weng SCK, Gabriel TM, Villafuerte LL, et al. Consensus guidelines for the management of atopic dermatitis: An Asia-Pacific perspective. J Dermatolog, 2013; 40(3): 160-71.

14. Xu Y, Zhi-Qiang S, Wei L, Yun-Sheng L, Yan Z, Hua C, et al. Guidelines for Diagnosis and Treatment of Atopic Dermatitis in China. Int. J. Dermatol. Venereol. 2021;4(1):1-9.

15. Sathishkumar D, Gupta A, Saini K. Atopic dermatitis in children: An update for pediatricians. Curr Med Issues 2020;18(3):17-25.

16. Mirrakhimova MK. Improving methods of Treatment of Atopic Pathology in Children. JCR 2020; 7(12):190-2. 